\title{
Ecological studies on ixodid ticks 7. The effects of humidity on oviposition, development and survival of Ixodes ovatus Neumann (Acarina: Ixodidae)
}

\author{
Kazuyoshi Fujıмото* \\ Department of Medical Zoology, Saitama Medical School, \\ Moroyama-cho, Iruma-gun, Saitama 350-04, Japan
}

(Received: April 25, 1990)

Key words: Ixodes ovatus, oviposition, development, survival, relative humidity.

\begin{abstract}
The oviposition, development and survival of Ixodes ovatus were studied at six different humidities $(52,68,74,86,95$ and 100\%) and at 20 and $25^{\circ} \mathrm{C}$. At both 20 and $25^{\circ} \mathrm{C}$, egg production occurred at 86 to $100 \% \mathrm{RH}$, but the mean number of deposited eggs per mg body weight of engorged female was scarce at $86 \% \mathrm{RH}$; accordingly, the duration of oviposition was shorter than that at 95-100\% RH. The preoviposition period increased with decreasing relative humidity. Hatching of eggs held at $100 \% \mathrm{RH}$ and $20-25^{\circ} \mathrm{C}$ averaged $57.2-63.8 \%$, but reduced to $1.6-17.7 \%$ at $95 \% \mathrm{RH}$, and none hatched at $86 \% \mathrm{RH}$ and below. At 95-100\% RH and $20-25^{\circ} \mathrm{C}, 45.1-74.3 \%$ of engorged larvae molted, but none molted at $86 \% \mathrm{RH}$ and below. At both 20 and $25^{\circ} \mathrm{C}$, molting of engorged nymphs to adults occurred at 86 to $100 \% \mathrm{RH}$, but the percentage of molting success was few at $86-95 \% \mathrm{RH}$. Weight loss of engorged nymphs increased with decreasing relative humidity. Longevity of unfed larvae, nymphs and adults decreased considerably as the relative humidity was lowered. Unfed larvae and nymphs were less tolerant to desiccating conditions than unfed adults. These results suggest that $I$. ovatus is more susceptible to desiccating conditions compared with other ixodid ticks, and this would play an important role in the distribution and abundance of this species.
\end{abstract}

\section{INTRODUGTION}

In order to clarify the factors that define the distribution and habitats of Ixodes ovatus, Fujimoto (1989) has studied the effects of temperature on oviposition, development and survival of this tick under laboratory conditions. The laboratory results showed that each stage of $I$. ovatus was more adversely affected by high $\left(27-30^{\circ} \mathrm{C}\right)$ and low $\left(15^{\circ} \mathrm{C}\right)$

* 藤本和義：埼玉医科大学医動物学教室（宁350-04 埼玉県入閒郡毛呂山町大字毛吕本郷 38) temperatures compared with common Japanese Haemaphysalis species, $H$. longicornis and $H$. flava (Fujimoto and Yamaguti, 1987). Many researchers have reported that humidity as well as temperature plays an important role in the development and survival of ticks: Amblyomma americanum (Lancaster and McMillan, 1955), Dermacentor variabilis (Sonenshine and Tigner. 1969), H. longicornis (Fujisaki et al., 1974; Heath, 1979, 1981), H. flava (Fujimoto, 1988), Ixodes hexagonus (Arthur, 1951), I. ricinus (Lees, 1946) and Rhipicephalus sanguineus (Koch and Tuck, 1986). For $I$. 
ovatus, however, there is no information concerning the effects of humidity. The purpose of the present study was to observe the effects of different relative humidities on development, survival and oviposition of $I$. ovatus under laboratory conditions and compare them with similar studies on other ixodid ticks.

\section{Materials and Methods}

Ticks used in this study were derived from adults collected by the flagging method in Saitama Prefecture. Larvae and nymphs were fed on albino mice, and adults on ears of domestic rabbits in the laboratory maintained at $25 \pm 3^{\circ} \mathrm{C}$ and with a photoperiod of L:D 16:8. Each host was used only once.

Laboratory experiments were conducted under six different relative humidities (52, 68, 74, 86, 95 and 100\%) and constant temperatures of 20 and $25^{\circ} \mathrm{C}$. Each relative humidity was obtained by filling the bottom of a desiccator with a certain saturated salt solution of $\mathrm{Ca}\left(\mathrm{NO}_{3}\right)_{2} \cdot 4 \mathrm{H}_{2} \mathrm{O}, \mathrm{NaNO}_{2}, \mathrm{NaCl}$, $\mathrm{KCl}$ and $\mathrm{Na}_{2} \mathrm{HPO}_{4} \cdot 12 \mathrm{H}_{2} \mathrm{O}$, for 52, 68, 74, 86 and $95 \%$, respectively. The desiccators, in which tick containers (Petri dishes of 3$4.5 \mathrm{~cm}$ in diameter) were placed, were kept in incubators maintained at 20 and $25^{\circ} \mathrm{C}$ with a photoperiod of $\mathrm{L}: \mathrm{D}$ 16:8. To obtain $100 \% \mathrm{RH}$, the bottom of a tick container was covered with a double sheet of filter paper on which drops of water were added at appropriate intervals to maintain the wet condition; the containers were also placed in the incubators as above. Temperature and relative humidity in each desiccator were checked regularly with a thermohydrometer.

Each engorged female was placed in a tick container and kept in different humidities after being weighed on a chemical balance (Shimadzu Co. Ltd., NL-200P), and examined daily to determine their preoviposition and oviposition periods. Some engorged females were allowed to oviposit without disturbance by daily examination. These undisturbed females were compared with females disturbed during the preoviposition and oviposition periods by daily examination. The number of deposited eggs was finally determined by counting hatched larvae and unhatched eggs. Observations of incubation period and hatching percentage were made on those eggs which were collected daily from ovipositing females kept at $100 \% \mathrm{RH}$. After a majority of larvae had hatched from the eggs, the number of larvae and unhatched eggs were counted to determine hatching percentage. Unhatched eggs were carefully examined under a stereomicroscope to determine if they could continue further embryonic development. They were taken to be dead when either depression of the surface was observed or there were no signs of normal embryonic development such as formation of rectal sac, Malpighian tubule, etc. Engorged larvae and nymphs dropped off from the host on the same day were placed together in batches of one to 10 specimens in Petri dishes at different humidities, and developmental period (days from drop-off to following ecdysis) and molting percentage were observed. Some engorged nymphs reared at various humidities were weighed in a batch of six specimens every day or every other day, and their weight loss was calculated. Unfed nymphs or adults molted on the same day from each preceding stage which had been held at $100 \% \mathrm{RH}$ were placed together in a tick container as a group of 1-10 individuals, and were observed for their longevity (days from ecdysis to death) under the different humidities.

\section{Results}

\section{Effect of humidity on oviposition}

The effect of relative humidity on the oviposition of females is summarized in Tables 1 and 2. At both 20 and $25^{\circ} \mathrm{C}$, egg production occurred at 86 to $100 \% \mathrm{RH}$, but no eggs were produced at $74 \% \mathrm{RH}$ and below. The percentage of oviposition of the females ranged from $81-93 \%$ at $95-100 \%$ $\mathrm{RH}$, but decreased to $50-62 \%$ at $86 \% \mathrm{RH}$. The duration of the preoviposition period was prolonged in the lower humidities, ranging from a mean of 12.4 to 18.1 days at $86-100 \% \mathrm{RH}$ and $20^{\circ} \mathrm{C}$, and from a mean of 9.6 to 13.2 days at the same $\mathrm{RH}$ and $25^{\circ} \mathrm{C}$. The mean days of the oviposition at $95-100 \% \mathrm{RH}$ and $20^{\circ} \mathrm{C}$ was $24.5-28.4$, about twice that at $86 \% \mathrm{RH}$. The mean number 
Table 1 Percent oviposition of engorged females of $I$. ovatus held at different humidities at 20 and $25^{\circ} \mathrm{C}$.

\begin{tabular}{ccccc}
\hline $\begin{array}{c}\text { Temp. } \\
\left({ }^{\circ} \mathrm{C}\right)\end{array}$ & $\begin{array}{c}\text { R.H. } \\
(\%)\end{array}$ & $\begin{array}{c}\text { No. of females } \\
\text { observed }\end{array}$ & $\begin{array}{c}\text { No. of females } \\
\text { oviposited }\end{array}$ & $\begin{array}{c}\text { Percent oviposition } \\
(\%)\end{array}$ \\
\hline 20 & 68 & 5 & 0 & 0 \\
& 74 & 5 & 0 & 0 \\
& 86 & 13 & 8 & 61.5 \\
& 95 & 15 & 14 & 93.3 \\
& 100 & 20 & 18 & 90.0 \\
\hline 25 & 68 & 3 & 0 & 0 \\
& 74 & 4 & 0 & 0 \\
& 86 & 14 & 7 & 50.0 \\
& 95 & 16 & 14 & 87.5 \\
& 100 & 36 & 29 & 80.6 \\
\hline
\end{tabular}

Table 2 Fertility, preoviposition and oviposition periods of $I$. ovatus females held at different humidities at 20 and $25^{\circ} \mathrm{C}$.

\begin{tabular}{|c|c|c|c|c|c|}
\hline$\underset{\left({ }^{\circ} \mathbf{C}\right)}{\text { Temp. }}$ & $\underset{(\%)}{\text { R.H. }}$ & $\begin{array}{l}\text { No. of females } \\
\text { observed }\end{array}$ & $\begin{array}{l}\text { Preoviposition } \\
\text { period in } \\
\text { days } \pm \text { S.D. }\end{array}$ & $\begin{array}{l}\text { Oviposition } \\
\text { period in } \\
\text { days } \pm \text { S.D. }\end{array}$ & $\begin{array}{l}\text { Mean no. of eggs } \\
\text { per mg body } \\
\text { weight } \pm \text { S.D. }\end{array}$ \\
\hline \multirow[t]{8}{*}{20} & 68 & 5 & No oviposition & No oviposition & 0 \\
\hline & 74 & 5 & No oviposition & No oviposition & 0 \\
\hline & 86 & 4 & $18.1 \pm 3.2$ & $13.4 \pm 4.0$ & $2.7 \pm 2.2$ \\
\hline & & $(4)$ & & & $(2.3 \pm 0.9)$ \\
\hline & 95 & 6 & $12.9 \pm 1.9$ & $24.5 \pm 2.6$ & $9.4 \pm 1.3$ \\
\hline & & (8) & & & $(11.5 \pm 0.8)$ \\
\hline & 100 & 8 & $12.4 \pm 0.7$ & $28.4 \pm 9.6$ & $12.3 \pm 1.6$ \\
\hline & & $(10)$ & & & $(10.5 \pm 4.1)$ \\
\hline \multirow[t]{8}{*}{25} & 68 & 3 & No oviposition & No oviposition & 0 \\
\hline & 74 & 4 & No oviposition & No oviposition & 0 \\
\hline & 86 & 3 & $13.2 \pm 4.3$ & $12.3 \pm 1.5$ & $3.6 \pm 1.9$ \\
\hline & & (4) & & & $(0.6 \pm 0.8)$ \\
\hline & 95 & 6 & $10.6 \pm 1.3$ & $19.0 \pm 10.8$ & $5.9 \pm 3.5$ \\
\hline & & $(8)$ & & & $(11.2 \pm 1.2)$ \\
\hline & 100 & 17 & $9.6 \pm 1.7$ & $14.5 \pm 6.8$ & $10.6 \pm 4.8$ \\
\hline & & (12) & & & $(9.1 \pm 3.7)$ \\
\hline
\end{tabular}

Figures in parentheses show the data of undisturbed females.

of deposited eggs per mg body weight of engorged female (both disturbed and undisturbed females) was considerably decreased at $86 \% \mathrm{RH}$ and $20^{\circ} \mathrm{C}$. The mean duration of the oviposition at $95-100 \% \mathrm{RH}$ and $25^{\circ} \mathrm{C}$ was 14.5-19.0 days, which was longer than that at $86 \% \mathrm{RH}$. The mean number of deposited eggs per mg body weight of disturbed female at $95-100 \% \mathrm{RH}$ and $25^{\circ} \mathrm{C}$ was 5.9-10.6 (undisturbed females=9.111.2 ), about 1.5 - to 3 -times that at $86 \%$ $\mathrm{RH}$.

The pattern of oviposition at $25^{\circ} \mathrm{C}$ did not vary among three humidities (86, 95 and $100 \% \mathrm{RH}$ ) except that the duration of the oviposition was shorter at $86 \%$ RH. Egg production reached a peak between the 12 th to 14th day after drop-off at all humidities 
(86-100\% RH), and then gradually declined until oviposition ceased (Fig. 1). The pattern of oviposition at $20^{\circ} \mathrm{C}$ was similar to that at $25^{\circ} \mathrm{C}$ except that egg production at $86 \% \mathrm{RH}$ had two peaks due to disturbance by repeated handlings. The maximum egg production was seen between the 17 th and 19th day after drop-off at all humidities $(86-100 \% \mathrm{RH})$ and was followed by a gradual decrease.

\section{Effect of humidity on egg hatching}

The hatching percentage and the incubation period of eggs held at different humidities at 20 and $25^{\circ} \mathrm{C}$ are shown in Table 3 . Hatching of disturbed eggs held at $100 \%$ $\mathrm{RH}$ and $20-25^{\circ} \mathrm{C}$ averaged $57.2-63.8 \%$, but reduced to $1.6-17.7 \%$ at $95 \% \mathrm{RH}$, and all eggs failed to hatch at $86 \% \mathrm{RH}$ and below, though signs of embryonic development were observed. Undisturbed eggs also hatched in a humidity range of 95 to $100 \% \mathrm{RH}$, but the hatchability did not decrease at $95 \%$ $\mathrm{RH}$. The mean incubation period of eggs at $20^{\circ} \mathrm{C}$ was shortened at $95 \% \mathrm{RH}(56.4$ days) compared to $100 \% \mathrm{RH}$ (74.5 days).

3. Effect of humidity on survival of engorged immature ticks and on molting success

The developmental period and molting success of engorged larvae and nymphs incubated at humidities from 74 to $100 \% \mathrm{RH}$ are shown in Table 4. At 95-100\% RH and
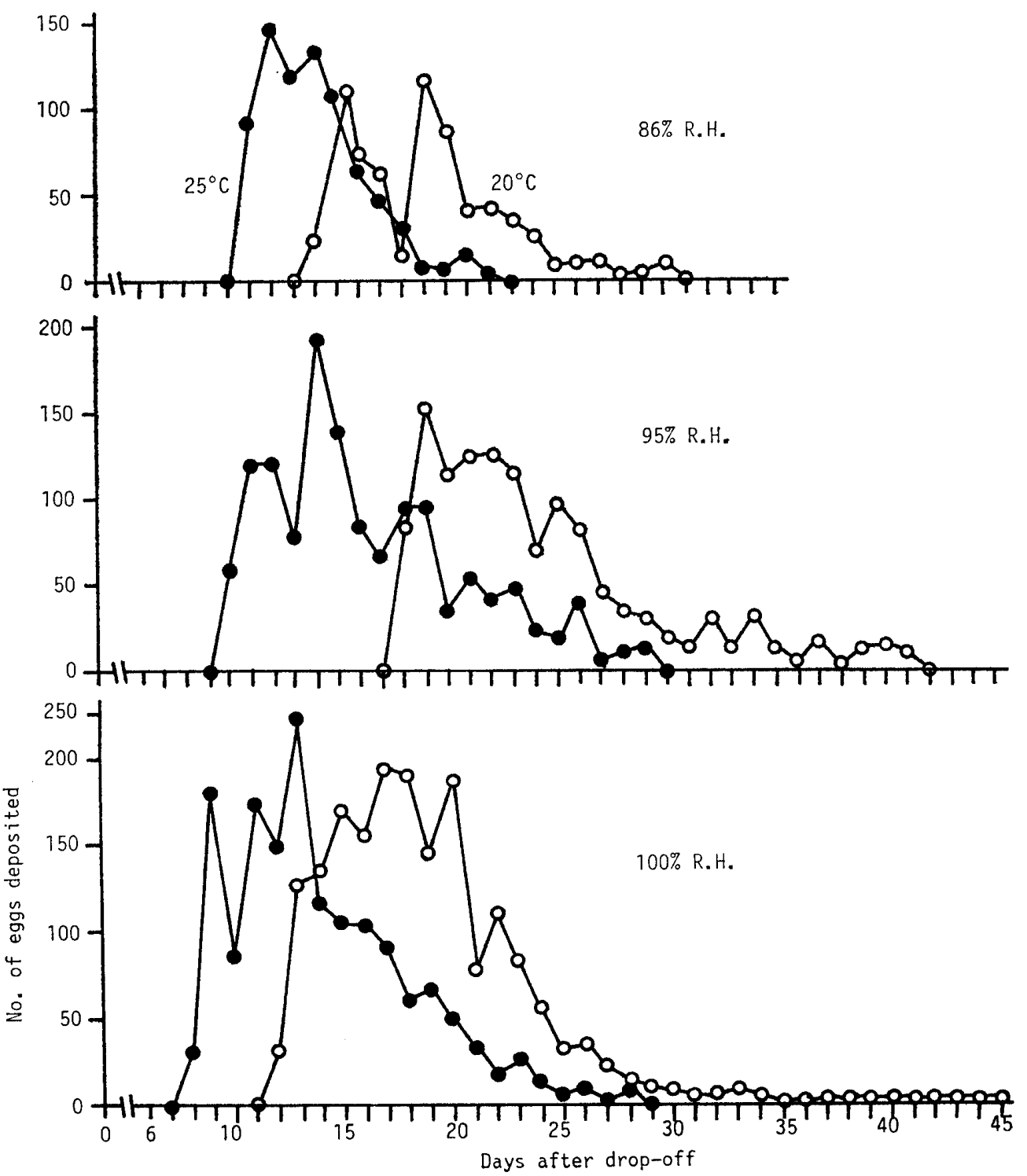

Fig. 1 Typical oviposition patterns of $I$. ovatus held at different humidities at 20 and $25^{\circ} \mathrm{C}$. 
$20-25^{\circ} \mathrm{C}, 45.1-74.3 \%$ of engorged larvae molted to nymphs, but no molting occurred at $74-86 \%$ RH. Development from the engorged nymph to an unfed adult occurred in a humidity range of 86 to $100 \% \mathrm{RH}$ at both 20 and $25^{\circ} \mathrm{C}$. Relatively high molting percentage was observed at $100 \% \mathrm{RH}$ and $25^{\circ} \mathrm{C}$, where $45.6 \%$ of engorged nymphs molted to adults, but only $22.2-22.4 \%$ molted at $86-95 \% \mathrm{RH}$. At $100 \% \mathrm{RH}$ and $20^{\circ} \mathrm{C}$, $21.9 \%$ of engorged nymphs molted to adults, but only a small percentage (1.5-4.2\%) molted at $86-95 \% \mathrm{RH}$. At $95-100 \% \mathrm{RH}$ and $20^{\circ} \mathrm{C}$, the developmental period of engorged larvae ranged from a mean of 39.6 to 45.8 days and from a mean of 34.4 to

Table 3 Percentage of hatchability and incubation period of eggs of $I$. ovatus held at different humidities at 20 and $25^{\circ} \mathrm{C}$.

\begin{tabular}{|c|c|c|c|c|c|}
\hline $\begin{array}{c}\text { Temp. } \\
\left({ }^{\circ} \mathrm{C}\right)\end{array}$ & $\underset{(\%)}{\text { R.H. }}$ & $\begin{array}{l}\text { No. of eggs } \\
\text { examined }\end{array}$ & $\begin{array}{l}\text { No. of larvae } \\
\text { hatched }\end{array}$ & $\begin{array}{l}\text { Hatchability } \\
(\%)\end{array}$ & $\begin{array}{l}\text { Incubation period } \\
\text { (days) } \pm \text { S.D. }\end{array}$ \\
\hline \multirow[t]{8}{*}{20} & 68 & 1,010 & 0 & 0 & No hatch \\
\hline & 74 & 2,844 & 0 & 0 & No hatch \\
\hline & 86 & 1,959 & 0 & 0 & No hatch \\
\hline & & $(1,134)$ & $(0)$ & $(0)$ & \\
\hline & 95 & 1,708 & 302 & 17.7 & $74.5 \pm 4.1$ \\
\hline & & $(10,299)$ & $(6,589)$ & $(64.0)$ & \\
\hline & 100 & 7,557 & 4,321 & 57.2 & $56.4 \pm 5.9$ \\
\hline & & $(9,861)$ & $(4,993)$ & $(50.6)$ & \\
\hline \multirow[t]{8}{*}{25} & 68 & 353 & 0 & 0 & No hatch \\
\hline & 74 & 735 & 0 & 0 & No hatch \\
\hline & 86 & 1,826 & 0 & 0 & No hatch \\
\hline & & $(431)$ & (0) & $(0)$ & \\
\hline & 95 & 2,746 & 43 & 1.6 & - \\
\hline & & $(11,646)$ & $(3,402)$ & $(29.2)$ & \\
\hline & 100 & 17,647 & 11,266 & 63.8 & $47.2 \pm 2.6$ \\
\hline & & $(14,800)$ & $(4,169)$ & $(28.2)$ & \\
\hline
\end{tabular}

Figures in parentheses show the hatchability of eggs deposited by undisturbed females.

Table 4 Developmental period and percentage molting success of engorged larvae and nymphs of $I$. ovatus held at different humidities at 20 and $25^{\circ} \mathrm{C}$.

\begin{tabular}{|c|c|c|c|c|c|c|c|}
\hline \multirow{2}{*}{$\underset{\left({ }^{\circ} \mathrm{C}\right)}{\text { Temp. }}$} & \multirow{2}{*}{$\underset{(\%)}{\text { R.H. }}$} & \multicolumn{3}{|c|}{ Larvae } & \multicolumn{3}{|c|}{ Nymphs } \\
\hline & & No. & $\%$ molting & $\begin{array}{c}\text { Developmental } \\
\text { period* (days) } \pm \text { S.D. }^{*}\end{array}$ & No. & $\%$ molting & $\begin{array}{c}\text { Developmental } \\
\text { period* (days) } \pm \text { S.D. }^{*}\end{array}$ \\
\hline \multirow[t]{4}{*}{20} & 74 & 46 & 0 & - & 34 & 0 & - \\
\hline & 86 & 50 & 0 & - & 65 & 1.5 & - \\
\hline & 95 & 60 & 60.0 & $45.8 \pm 4.69$ & 48 & 4.2 & $52.5 \pm 2.12$ \\
\hline & 100 & 304 & 74.3 & $39.6 \pm 2.95$ & 169 & 21.9 & $48.4 \pm 6.99$ \\
\hline \multirow[t]{4}{*}{25} & 74 & 26 & 0 & - & 32 & 0 & - \\
\hline & 86 & 53 & 0 & - & 27 & 22.2 & $46.3 \pm 5.68$ \\
\hline & 95 & 51 & 45.1 & $41.4 \pm 3.89$ & 107 & 22.4 & $37.9 \pm 4.32$ \\
\hline & 100 & 793 & 69.6 & $34.4 \pm 2.77$ & 169 & 45.6 & $41.6 \pm 4.06$ \\
\hline
\end{tabular}

* Developmental period was monitored from time dropped off host to molting. 
41.4 days at the same $\mathrm{RH}$ and $25^{\circ} \mathrm{C}$. At both 20 and $25^{\circ} \mathrm{C}$, engorged larvae held at $95 \% \mathrm{RH}$ took longer to molt than those held at $100 \%$ RH. The developmental period of engorged nymphs ranged from a mean of 48.4 to 52.5 days at $95-100 \% \mathrm{RH}$ and $20^{\circ} \mathrm{C}$ and from a mean of 41.6 to 46.3 days at $86-100 \% \mathrm{RH}$ and $25^{\circ} \mathrm{C}$. At $20^{\circ} \mathrm{C}$, the developmental period of engorged nymphs was more prolonged at $95 \% \mathrm{RH}$ than at $100 \% \mathrm{RH}$, but at $25^{\circ} \mathrm{C}$, the minimum developmental period was observed at $95 \%$ $\mathrm{RH}$.
4. Effect of humidity on weight loss of engorged nymphs

Weight loss of engorged nymphs was observed under different humidities, and the mean percentage of the loss was compared between $I$. ovatus and $H$. flava (Fig. 2). The difference in weight losses of the two species grew greater with decreasing humidity. At $95 \% \mathrm{RH}$, the rates of weight loss did not differ distinctly between these two species, but at $86 \% \mathrm{RH}$ the loss of the original weight up to the 15th day after drop-off was $36 \%$ in I. ovatus, while $26 \%$ in $H$. flava. At $74 \%$

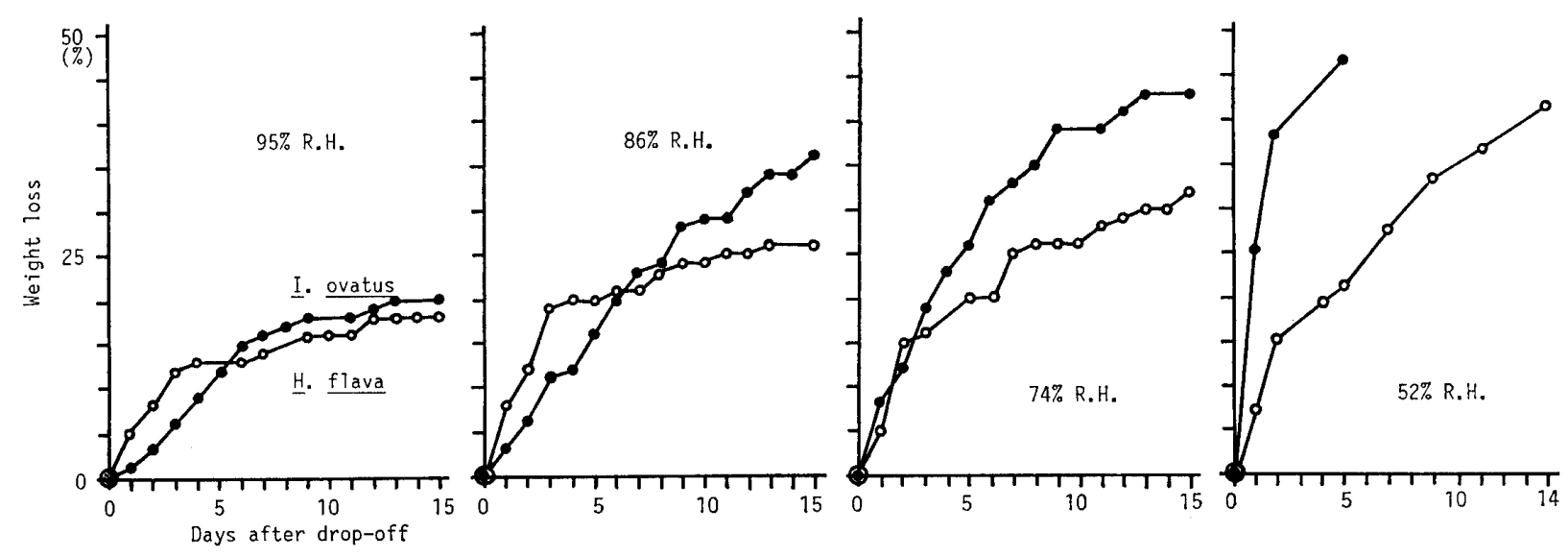

Fig. 2 Weight loss of engorged nymphs of $I$. ovatus compared with $H$. flava at different relative humidities at $25^{\circ} \mathrm{C}$.

Weight loss is indicated by data from a batch of six engorged nymphs. H. flava nymphs were collected by flagging method and fed on rabbits.

Table 5 Longevity of unfed adults, nymphs and larvae of $\boldsymbol{I}$. ovatus held at different humiditics at 20 and $25^{\circ} \mathrm{C}$.

\begin{tabular}{|c|c|c|c|c|c|c|c|}
\hline \multirow{2}{*}{$\underset{\left({ }^{\circ} \mathrm{C}\right)}{\text { Temp. }}$} & \multirow{2}{*}{$\underset{(\%)}{\text { R.H. }}$} & \multicolumn{2}{|r|}{ Larvae } & \multicolumn{2}{|r|}{ Nymphs } & \multicolumn{2}{|c|}{ Adults } \\
\hline & & No. & $\begin{array}{l}\text { Longevity in } \\
\text { days (mean) }\end{array}$ & No. & $\begin{array}{l}\text { Longevity in } \\
\text { days (mean) }\end{array}$ & No. & $\begin{array}{l}\text { Longevity in } \\
\text { days (mean) }\end{array}$ \\
\hline \multirow[t]{3}{*}{20} & 74 & 40 & $1-3 \quad(1.5)$ & 30 & $1-3(1.6)$ & 15 & $1-10 \quad(3.6)$ \\
\hline & 86 & 41 & $1-3 \quad(1.7)$ & 30 & $1-6 \quad(3.4)$ & 15 & $1-55 \quad(14.8)$ \\
\hline & 95 & 65 & $\begin{array}{c}1-12 \quad(3.3, n=46) \\
80< \\
(n=19)\end{array}$ & 31 & $\begin{array}{c}1-12(3.1, n=10) \\
42< \\
(n=21)\end{array}$ & 18 & $60<$ \\
\hline \multirow[t]{3}{*}{25} & 74 & 50 & $1-2(1.1)$ & 57 & $1-2 \quad(1.1)$ & 20 & $2-16 \quad(6.2)$ \\
\hline & 86 & 50 & $1-2(1.2)$ & 45 & $1-5(1.2)$ & 18 & $1-25 \quad(6.3)$ \\
\hline & 95 & 40 & $\begin{array}{c}1-8 \quad(2.7, n=36) \\
80< \\
(n=4)\end{array}$ & 34 & $\begin{array}{c}1-2(1.3, n=6) \\
40< \\
(n=28)\end{array}$ & 15 & $56<$ \\
\hline
\end{tabular}


$\mathrm{RH}$, furthermore, I. ovatus lost $31 \%$ of the original weight up to the 7 th day, and $41 \%$ up to the 15 th day, while $H$. flava lost only 20 and $30 \%$, respectively. At $52 \% \mathrm{RH}, \dot{I}$. ovatus lost $38 \%$ up to the second day, and $47 \%$ up to the 5 th day, whereas $H$. flava lost only 16 and $21 \%$, respectively.

\section{Effect of humidity on the longevity of unfed ticks}

The mean longevity of unfed larvae, nymphs and adults in relation to the relative humidity is shown in Table 5. At 74-86\% $\mathrm{RH}$, unfed larvae survived for only 1-3 days at $20^{\circ} \mathrm{C}$ and $1-2$ days at $25^{\circ} \mathrm{C}$. At $95 \%$ $\mathrm{RH}$, however, some larvae survived for longer than 80 days at both 20 and $25^{\circ} \mathrm{C}$. All unfed nymphs held at $74-86 \% \mathrm{RH}$ had died after 6 days at both 20 and $25^{\circ} \mathrm{C}$. At $95 \% \mathrm{RH}$, however, some nymphs survived for 40 days and more. Unfed adults survived 2.2- to 6-times longer than nymphs and larvae at $74-86 \% \mathrm{RH}$. At $74-86 \% \mathrm{RH}$, the length of survival for adults was $1-55$ days at $20^{\circ} \mathrm{C}$ and 1-25 days at $25^{\circ} \mathrm{C}$, and at $95 \% \mathrm{RH}$ all adults survived for longer than 56 days at both 20 and $25^{\circ} \mathrm{C}$.

\section{Discussion}

It is known that many unfed ticks can withstand long periods of starvation in the absence of suitable hosts. The longevity of a tick depends primarily on the relative humidity of the air (Knülle, 1966). Many researchers have reported that the survival, development and molting of engorged ticks are also much influenced by the relative humidity to which they are exposed (MacLeod, 1934, 1935; Feldman-Muhsam, 1947; Arthur, 1951; Sonenshine and Tigner, 1969; Fujisaki et al., 1974; Fujimoto, 1988). Thus, humidity, together with temperature, has considerable influence on the distribution and abundance of ticks (Heath, 1979, 1981; Koch and Tuck, 1986).

In the present study, the development and survival of $I$. ovatus were almost impossible under low relative humidities. Engorged $I$. ovatus females oviposited under a narrow range of high relative humidity; also, the eggs and postembryonic immature stages were strongly affected by the relative humidity.
Especially, ixodid ticks of the genus Ixodes seem to be susceptible to desiccation (Lees, 1946). However, the lower humidity limit for the survival and development of $I$. ovatus was higher than that for other species of the same genus, such as I. ricinus (MacLeod, 1934, 1935), I. hexagonus (Arthur, 1951) and I. aulacodi (Ntiamoa-Baidu, 1987).

Unfed ticks generally have the ability to absorb water from the atmosphere to maintain water balance in the body (Lees, 1946). However, this active absorption has functional limits (generally between 74 and 95\% $\mathrm{RH}$ ). Thus, if unfed ticks were exposed to an extremely desiccating condition, they would lose water rapidly through the cuticle and spiracles and die of dehydration. It may be due to high rates of water loss that the longevity of unfed larvae, nymphs and adults in the present study was markedly shortened at $74-86 \% \mathrm{RH}$ (Table 5). The longevity of unfed larvae and nymphs was shorter than that of unfed adults at all humidities as listed in Table 5 . This may be correlated with the surface/volume ratio; the ratio is larger in larvae and nymphs than in adults, and, consequently, immature stages are ready to suffer from a high water loss.

It was generally assumed that engorged ixodid ticks and the eggs do not have the ability to absorb water from the atmosphere (Lees, 1946; Sauer and Hair, 1971; Heath, 1979; Knülle and Rudolph, 1982). Kahl and Knülle (1988), however, have shown that engorged larvae and nymphs of some ixodid ticks consistently take up substantial amount of atmospheric water vapour. In the present study, engorged $I$. ovatus larvae and nymphs were hardly able to molt at $74-86 \% \mathrm{RH}$ (Table 4 ). In addition, the engorged nymphs of $I$. ovatus, compared with $H$. flava, lost water more rapidly with decreasing humidity (Fig. 2). It is not clear from these experiments whether engorged $I$. ovatus larvae and nymphs can take up water vapour from the atmosphere, but the present results suggest that the minimum humidity limit for survival of engorged $I$. ovatus larvae and nymphs is above $86 \% \mathrm{RH}$, which is higher than that for engorged $H$. flava. Lees (1946) described that the differential susceptibility to desiccation seen among tick species can essentially be attributed to differences in water perme- 
ability of the tick integument which is primarily due to the molecular nature of waxy lipids of the epicuticle. Further, Knülle and Rudolph (1982) pointed out that the transition temperature of the epicuticular lipids of ticks is associated with the degree of cuticular impermeability to water. In the present study, the low tolerance of engorged $I$. ovatus to desiccation may be related to the nature of waxy lipids of the epicuticle.

These results suggest that each stage of I. ovatus can survive only in highly moist condition and the longevity rapidly decreases with decreasing RH's below $86 \% \mathrm{RH}$.

\section{Acknowledgements}

I would like to thank Professors E. Hori (Saitama Medical School) and N. Yamaguti (Junior College, Saitama Medical School) for their critical reading of the manuscript and helpful discussion.

\section{References}

Arthur, D. R. (1951): The bionomics of Ixodes hexagonus Leach in Britain. Parasitology, 41: 82-90.

Feldman-Muhsam, B. (1947): Resistance of larvae and nymphs of Hyalomma savignyi Gev. to various conditions of temperature and humidity. Parasitology, 38: 111-115.

Fujimoto, K. (1988): Ecological studies on ixodid ticks. 5. The effect of humidity on the oviposition and development of Haemaphysalis longicornis and $H$. flava (Acarina: Ixodidae). Jpn. J. Sanit. Zool., 39: 27-33 (in Japanese).

Fujimoto, K. (1989): Ecological studies on ixodid ticks. 6. The effects of temperature on the oviposition, development and survival of Ixodes ovatus Neumann (Acarina: Ixodidae). Jpn. J. Sanit. Zool., 40: 187-193.

Fujimoto, K. and N. Yamaguti (1987): Ecological studies on ixodid ticks. 4. The effect of temperature on the oviposition and development of Haemaphysalis longicornis and H. flava (Acarina: Ixodidae). Jpn. J. Sanit. Zool., 38: 225232 (in Japanese).

Fujisaki, K., S. Kitaoka and T. Morii (1974): Effect of different combinations of temperature and humidity on the oviposition of Haemaphysalis longicornis and Boophilus microplus. Bull. Natl. Inst. Anim. Health, 70: 27-34 (in Japanese).

Heath, A. C. G. (1979): The temperature and humidity preferences of Haemaphysalis longicornis, Ixodes holocylus and Rhipicephalus sanguineus (Ixodidae): Studies on eggs. Int. J.
Parasitol., 9: 33-39.

Heath, A. C. G. (1981): The temperature and humidity preferences of Haemaphysalis longicornis, Ixodes holocylus and Rhipicephalus sanguineus (Ixodidae): Studies on engorged larvae. Int. J. Parasitol., 11: 169-175.

Kahl, O. and W. Knülle (1988): Water vapour uptake from subsaturated atmospheres by engorged immature ixodid ticks. Exp. Appl. Acarol., 4: 73-83.

Knülle, W. (1966): Equilibrium humidities and survival of some tick larvae. J. Med. Entomol., 2: 335-338.

Knülle, W. and D. Rudolph (1982): Humidity relationships and water balance of ticks. In: Physiology of Ticks (eds., Obenchain, F. D. and R. Galun), pp. 43-70, Pergamon Press, Oxford.

Koch, H. G. and M. D. Tuck (1986): Molting and survival of the brown dog tick (Acari: Ixodidae) under different temperatures and humidities. Ann. Entomol. Soc. Am., 79: 11-14.

Lancaster, J. L., Jr. and H. L. McMillan (1955): The effects of relative humidity on the lone star tick. J. Econ. Entomol., 48: 338-339.

Lees, A. D. (1946): The water balance in Ixodes ricinus L. and certain other species of ticks. Parasitology, 37: 1-20.

MacLeod, J. (1934): Ixodes ricinus in relation to its physical environment: The influence of climate on development. Parasitology, 26: 282305.

MacLeod, J. (1935): Ixodes ricinus in relation to physical environment. III. Climate and reproduction. Parasitology, 27: 489-500.

Ntiamoa-Baidu, Y. (1987): Life cycle of Ixodes (Afrixodes) aulacodi (Acari: Ixodidae) in the laboratory. J. Med. Entomol., 24: 444-447.

Sauer, J. R. and J. A. Hair (1971): Water balance in the lone star tick (Acarina: Ixodidae): The effects of relative humidity and temperature on weight changes and total water content. J. Med. Entomol., 8: 479-485.

Sonenshine, D. E. and J. A. Tigner (1969) : Oviposition and hatching in two species of ticks in relation to moisture deficit. Ann. Entomol. Soc. Am., 62: 628-640.

$$
\begin{gathered}
\text { 摘 要 } \\
\text { マダニ類の生態学的研究 } \\
\text { 7. ヤマトマニ゙ニ産卯, 発育および } \\
\text { 生存における湿度の影響 }
\end{gathered}
$$

ヤマトマダニの産卵，発育および生存における湿度 の影響を， $20^{\circ} \mathrm{C}$ と $25^{\circ} \mathrm{C}$ 温度条件下で調べた. 産卵 は $20^{\circ} \mathrm{C}, 25^{\circ} \mathrm{C}$ とも相対湿度（以下，単に湿度） $86 \%$ から 100\%の閒でみられた。しかし，雌体重 $1 \mathrm{mg}$ あ たりの産卵数は $86 \% の$ 湿度で極端に減少し，産卵期間 
も短くなった．産卵前期間は湿度が低下するにつれて 長くなった， $20 \sim 25^{\circ} \mathrm{C}$ での卵の躬化率は，湿度 $100 \%$ では 57.2〜63.8\%であったが, 95\%の湿度では1.6〜 $17.7 \%$ に低下し，86\%以下の湿度ではまったく躬化し なかった. $20 \sim 25^{\circ} \mathrm{C}$ での飽血幼虫の脱皮率は湿度 95 100\%では 45.1〜74.3\%であったが, 86\%以下の湿度 ではまったく脱皮がみられなかった. 飽血若虫の脱皮 は $20^{\circ} \mathrm{C}, 25^{\circ} \mathrm{C}$ とも湿度 $86 \%$ から $100 \%$ までみられた
が，86〜95\%の湿度では脱皮率が極端に低下した. 飽 血若虫の体重の減少率は湿度が低下寸るにつれて大き くなった. 未吸血の幼虫, 若虫, 成虫の寿命は湿度が 低下寸るにつれて短くなったが，とくに幼・若虫にお いて顕著であった.

以上の結果はヤマトマダニが乾燥条件下にきわめて 弱いことを示しており, 湿度条件は本種の分布や生息 密度に重大な影響を及ぼすものと思われた。 